\title{
Synthesis of Graphene Oxide/Polypyrrole (GO/PPy) from Used Batteries as Electrodes in Supercapacitor Cells
}

\section{Muhammad Iqbal Qeis, Ferdian Rizki Amanda, Desi Listiani, Anthoni B. Aritonang, Intan Syahbanu*}

\author{
Department of Chemistry, Faculty of Mathematics and Natural Sciences, Tanjungpura University \\ Jl. Prof. Dr. H. Hadari Nawawi, Pontianak 78124, Indonesia \\ *Corresponding author: intan.syahbanu@chemistry.untan.ac.id
}

Received: Julyl 2019; Revision: September 2019; Accepted: October 2019; Available online: November 2019

\begin{abstract}
Fabrication of graphite-modified GO/PPy composites have been studied from used batteries using the Hummers method. This research was performed in four steps: graphite powder preparation, GO synthesis, GO/PPy composite synthesis, and supercapacitor cell manufacturing. The fabricated GO/PPy composite were characterized using X-Ray Diffraction (XRD) to investigate the characteristic of the diffraction patterns formed by carbon batteries used before and after calcination and Fourier Transform Infra-Red (FTIR) to identify compound functional groups and conduct initial tests in the form of voltage, capacitance and life cycle by measuring charge and discharge times. The graphite preparation stage is carried out by the calcination method at $900^{\circ} \mathrm{C}$ to produce graphite with an angle of $2 \theta$ which is $26^{\circ}$ with reflection from $\left(\mathrm{d}_{002}\right)$. FTIR data showed that GO/PPy composites showed a successful combination of characteristics similar to pure polypyrrole and GO which included a broad absorption band located at $3500-2300 \mathrm{~cm}^{-1}$ which was estimated to be stretching the amine from polypyrrole and $\mathrm{O}-\mathrm{H}$ group in the GO layer and the emergence of peaks new in the absorption band with a wave number $909 \mathrm{~cm}^{-1}$ is the $\mathrm{CN}$ vibration of the polymerized pyrrole. Meanwhile, based on the LCR meter measurement results in the best supercapacitor cells in the sampel GO/PPy ratio (3:10) with voltage value of $74.1 \mathrm{mV}$; a capacitance value of $15.14 \mu \mathrm{F}$ and the best charge and discharge times.
\end{abstract}

Keywords: Used battery, GO/PPy composite, supercapacitor cells.

\begin{abstract}
Abstrak
Telah dilakukan pembuatan komposit GO/PPy termodifikasi grafit dari baterai bekas dengan metode Hummers. Penelitian ini dilakukan dalam empat tahap yaitu preparasi serbuk grafit, sintesis GO, sintesis komposit GO/PPy, dan pembuatan sel superkapasitor. Hasil penelitian dikarakterisasi menggunakan X-Ray Diffraction (XRD) untuk melihat karakter dari pola difraksi yang dibentuk oleh serbuk karbon baterai bekas sebelum dan sesudah kalsinasi dan Fourier Transform Infra-Red (FTIR) untuk mengidentifikasi gugus fungsi senyawa serta melakukan pengujian awal berupa tegangan, kapasitansi dan siklus hidup dengan mengukur waktu pengisian dan pengosongan muatan. Tahap preparasi grafit dilakukan dengan metode kalsinasi pada suhu $900^{\circ} \mathrm{C}$ menghasilkan grafit dengan sudut $2 \theta$ yaitu $26^{\circ}$ dengan refleksi dari bidang $\left(\mathrm{d}_{002}\right)$. Data FTIR menunjukkan bahwa komposit GO/PPy memperlihatkan berhasilnya kombinasi karakteristik yang mirip dengan polipirol murni dan GO yang mencakup pita serapan luas yang terletak pada $3500-2300 \mathrm{~cm}^{-1}$ yang diperkirakan ini adalah peregangan amina dari polipirol dan kelompok O-H di lapisan GO serta munculnya puncak baru pada pita serapan dengan bilangan gelombang $909 \mathrm{~cm}^{-1}$ adalah vibrasi C-N dari pirol yang telah terpolimerisasi. Sementara itu, berdasarkan hasil pengukuran LCR meter menghasilkan sel superkapasitor terbaik pada sampel GO/PPy perbandingan (3:10) dengan nilai tegangan $74,1 \mathrm{mV}$, nilai kapasitansi $15,14 \mu \mathrm{F}$ dan waktu pengisian serta pengosongan muatan terbaik.
\end{abstract}

Kata kunci: Baterai bekas, komposit GO/PPy, sel superkapasitor.

DOI: $10.15408 / j k v \cdot v 5 i 2.11714$ 


\section{INTRODUCTION}

The rapid development of the electronics industry is pushing the digitalization era which requires an electrical energy storage device such as a battery. However, the short lifetime of battery will produces waste. Based on the Decree of the Minister of Industry No: 148/MISK/1985, mention that battery waste (used batteries) is classified as B3 (Material, Dangerous and Toxic) which can cause heavy metal pollution which will damage the surrounding environment if exposed to the battery waste. Many effort that can reduce this problem is by developing energy storage devices other than batteries, one of which is the supercapacitor. Supercapacitors show a great advantage over secondary (rechargeable) batteries because they display unique capabilities in high instantaneous power densities, fast charging or emptying processes, low maintenance costs, long life cycles, and are environmentally friendly (Winter and Brodd), 2004; Liu et al., 2010; Zhai et al., 2011; Wang et al., 2012).

One component of the supercapacitor circuit is the electrode. Electrode selection is usually chosen from carbon materials that have large pores with high surface area, high conductivity, inexpensive, and are easily available (Stoller et al., 2008). One material that has the potential to be developed as a supercapacitor electrode is graphene oxide (GO) and polypyrrole (PPy). In recent years there have been many studies related to graphene oxide/polypyrrole (GO/PPy) composite materials for applications as supercapacitors because they have a capacitance of 332-633 $\mathrm{F} \mathrm{g}^{-1}$ ( $\mathrm{Li}$ and Xie, 2012; Salas et al., 2014). This capacitance is very dependent on the preparation method of the GO/PPy composite and composite surface so that the results are very good in performance as a supercapacitor electrode.

The innovation in this research is related to GO synthesis using graphite precursors from used battery carbon and then made a composite with PPy through in-situ polymerization with variations in the mass of GO to PPy to study its potential as an electrode in supercapacitor cells. Synthesized composite of GO/PPy were further characterized using analytical X-Ray Diffraction (XRD) to see the character of a diffraction pattern formed by carbon powder used battery before and after calcination and Fourier Transform Infra-Red
(FTIR) to identify functional groups of compounds, and test the amount of capacitance and life cycle measured when charging and discharging the charge generated by the GO/PPy electrode.

\section{MATERIALS AND METHODS Instruments and Materials}

The instrument used in this study include a set of standard glassware, furnaces, hotplates, magnetic stirrers, mortars and pestle, SANWA multimeters (CD800A), KRISBOW LCR meters (KW0600489), analytical balance, ovens, funnel buchers, vacuum pumps, $\mathrm{pH}$ indicator strips (MColorpHast), ultrasonic (Branson 3510), centrifuge (Clement 2000), XRay Diffraction (PANalytical), and Fourier Transform Infra-Red (PerkinElmer Frontier).

The materials used are aquades, used batteries (ABC Dry Cell), $\mathrm{KMnO}_{4}$ (Amresco), $\mathrm{NaNO}_{3}$ (Merck), $\mathrm{H}_{2} \mathrm{SO}_{4}$ (Mallinckrodt), $\mathrm{HCl}$ (Mallinckrodt), $\quad \mathrm{H}_{2} \mathrm{O}_{2} \quad$ (Merck), Pyrrole (Aldrich), $\mathrm{FeCl}_{3}$ (Smart- Lab), PVA (Merck), and Aluminum (Merck).

\section{Graphite Powder Preparation}

This process refers to the research of Saraswati et al., (2016) which has been modified. Taking black bars contained in used batteries is done by opening the battery stone. Then the bar is continued by the refinement and sieving process with a size of 200 mesh. The powder that has been obtained is then carried out the calcination process with a temperature of $900{ }^{\circ} \mathrm{C}$ for 2 hours. The before and after powders from the preparation results were characterized using XRD analysis.

\section{GO Synthesis}

Graphene oxide was synthesized using the modified Hummers method (Hummers and Offeman, 1958). A total of 5 grams of graphite powder from the preparation and 2.5 grams of $\mathrm{NaNO}_{3}$ were mixed with $115 \mathrm{~mL} \mathrm{H}_{2} \mathrm{SO}_{4}$. This stirring process lasts for 1 hour in an ice bath. After stirring for 1 hour, 15 grams of $\mathrm{KMnO}_{4}$ is added gradually to the suspension. For 1.5 hours the temperature is maintained at temperatures below $20{ }^{\circ} \mathrm{C}$. After that, the suspension is stirred slowly for 30 minutes at $40{ }^{\circ} \mathrm{C}$ and $80 \mathrm{~mL}$ of distilled water added. The stirring process was continued for 90 minutes at $90{ }^{\circ} \mathrm{C}$ and $200 \mathrm{~mL}$ of distilled water and 15 $\mathrm{mL} \mathrm{H}_{2} \mathrm{O}_{2}$ was added. Finally, the filtering and washing process with $0.1 \mathrm{M} \mathrm{HCl}$ and distilled 
water to the same $\mathrm{pH}$ with distilled water. Furthermore, the residue obtained was then dissolved into $100 \mathrm{~mL}$ of distilled water and cultivated for 1 hour. The solution was centrifuged and the sludge was dried at $100{ }^{\circ} \mathrm{C}$. These results were characterized using FTIR and XRD.

\section{GO/PPy Composite Synthesis}

The method for GO/PPy composite synthesis refers to research by Liu et al., (2013). This method involves a comparison of the mass ratio of composite GO/PPy with $(1: 10,3: 10$, and 5:10). Briefly, the GO/PPy $1: 10$ composite was prepared by adding 0.2 grams of $\mathrm{GO}$ and $2.1 \mathrm{~mL}$ pyrrole then dissolved into $80 \mathrm{~mL}$ of distilled water. After the suspension is formed, ultrasonication was performed for 1 hour. Next, a stepwise addition of 0.49 grams of $\mathrm{FeCl}_{3}$ solution was added to $0.1 \mathrm{M} \mathrm{HCl}$ solution and allowed to proceed at room temperature for 24 hours. Then the mixture is filtered and washed with distilled water and ethanol. Finally, the obtained residue was heated at $60{ }^{\circ} \mathrm{C}$ for 24 hours. The above procedure is also carried out on a GO/PPy mass ratio (3:10, and 5:10). The results of the GO/PPy composite were characterized by FTIR and the capacitance measurements with charging and discharging time were controlled with carbon powder and GO/PPy (10:10).

\section{RESULTS AND DISCUSSION}

After disassembled all the components of the battery, carbon rod were obtained evwith a total mass of 150.123 grams. The refining process into a powder was conducted and resulting a grayish-black color powder. The results showed that the powder mixture after calcination at $900{ }^{\circ} \mathrm{C}$ with a grayish-black still has different masses. Therefore, the need to check the yield on the sample.

The result of graphite powder is the difference in mass of graphite powder after the calcination process of used carbon powder, the final mass $\left(\mathrm{M}_{1}\right)$ is the mass after calcination and the initial mass $\left(\mathrm{M}_{0}\right)$ is the mass before calcination. The graphite powder calcination process yields about $79.74 \%$. This is because organic substances or impurities decompose at $900{ }^{\circ} \mathrm{C}$ for 2 hours which are still attached to the paste attached to the electrolyte mixture $\left(\mathrm{MnO}_{2}\right.$ and $\left.\mathrm{NH}_{4} \mathrm{Cl}\right)$. This was supported from the results of the XRD analysis in Figure 1.
The results of XRD analysis is used to see the character of a diffraction pattern formed by carbon powder and graphite powder used batteries that have been through a calcination process by heating of $900{ }^{\circ} \mathrm{C}$. The $\mathrm{X}$-ray diffraction pattern for this study is shown in the diffractogram in Figure 1. The XRD data were compared with the results of Wachid and Darminto (2012) and supported by the ICDD data (PDF 03-065-6212). Based on the diffractogram, the diffraction pattern results from (Figure 1.a) carbon powder of the used battery showing a crystal structure with a sharp peak with a pattern similar to graphite diffraction $\left(\mathrm{d}_{002}\right)$ at an angle of $26.5^{\circ}$. However, there are still small peaks seen at an angle of $21.33^{\circ}$ and $23.70^{\circ}$, indicating that the powder is still attachment pasta mixture of electrolytes $\left(\mathrm{MnO}_{2}\right.$ and $\left.\mathrm{NH}_{4} \mathrm{Cl}\right)$. ICDD data (PDF 00-041-1487) also supports this, which states that compounds are still carbon.

After the calcination process, $900{ }^{\circ} \mathrm{C}$ for 2 hours (Figure 1.b) shows the peak intensity is higher and sharper than before calcination. This is because the impurity peaks had decomposed so that the diffraction peak of $26.47^{\circ}$ on the crystal field index $\left(\mathrm{d}_{002}\right)$ indicates that it has a graphite mineral phase and $54.6^{\circ}$ on the plane $\left(\mathrm{d}_{004}\right)$ and $83.6^{\circ}$ on the plane $\left(\mathrm{d}_{112}\right)$ which according to research Popova (2017). This is confirmed by the phase determination by the ICDD data (PDF 00-0560159) which states that graphite has diffraction typical of the plane of reflection $\left(\mathrm{d}_{002}\right),\left(\mathrm{d}_{004}\right)$, and $\left(\mathrm{d}_{112}\right)$ at an angle of $2 \theta=26.5^{\circ} ; 54.6^{\circ}$; and $83.5^{\circ}$. Based on of the pattern of X-ray diffraction identified that the angle $2 \theta=26.5^{\circ}$ with a distance of d-spacing of $3,36-3,37 \AA$ is a typical characteristic of graphite with a hexagonal structure (Fialkov, 1979).

The GO synthesis process is carried out to oxidized the graphite by adding $\mathrm{KMnO} 4$ slowly, this process causes the formation of oxidizing agent $\mathrm{Mn}_{2} \mathrm{O}_{7}$ from the reaction of strong acid $\mathrm{H}_{2} \mathrm{SO}_{4}$ with $\mathrm{KMnO}_{4}$. This agent can oxidize the unsaturated aliphatic double bonds from aromatic double bonds which may have important implications for the reaction pathways that occur during the oxidation process (Dreyer et al., 2010). The reaction that occurs between $\mathrm{KMnO}_{4}$ and $\mathrm{H}_{2} \mathrm{SO}_{4}$ is shown from the following equation (Hanifah et al., 2015): 
$\mathrm{KMnO}_{4}+3 \mathrm{H}_{2} \mathrm{SO}_{4} \longrightarrow \mathrm{K}^{+}+\mathrm{MnO}_{3}{ }^{+}+\mathrm{H}_{3} \mathrm{O}^{+}+3 \mathrm{HSO}_{4}^{-} \ldots \ldots \ldots . .(1)$

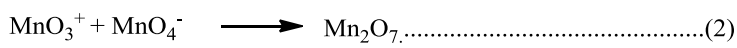

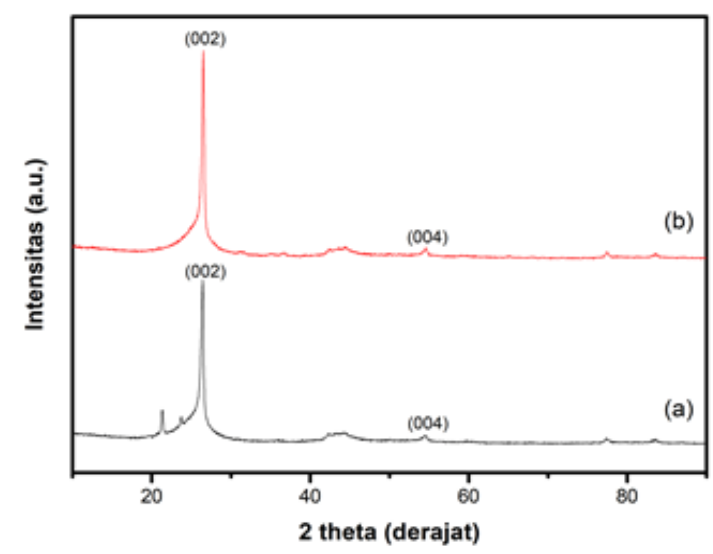

Figure 1. Diffraction pattern (a) used carbon powder, (b) after calcination $900{ }^{\circ} \mathrm{C}$

This mixture causes the solution to undergo a greenish-black color change (Figure 2.a) due to the reaction between graphite, $\mathrm{H}_{2} \mathrm{SO}_{4}$, and $\mathrm{KMnO}_{4}$, this indicates that the graphite oxidation process has begun. In order for the oxidation reaction to proceed perfectly followed by a stirring process at $40{ }^{\circ} \mathrm{C}$ with the addition of distilled water, the resulting mixture becomes purplish-black (Figure 2.b) accompanied by gas vapor so that this will result in an exothermic state with a temperature rise of up to $98{ }^{\circ} \mathrm{C}$ and shown by gas vapor which rises to the top (Junaidi and Susanti, 2014). The stirring process continued again at $90{ }^{\circ} \mathrm{C}$ with the addition of $\mathrm{H}_{2} \mathrm{O}$ and $\mathrm{H}_{2} \mathrm{O}_{2}$ and produced a brown mixture (Figure 2.c). The process of adding $\mathrm{H}_{2} \mathrm{O}_{2}$ acts to purify GO from the remnants of oxidizing agent $\left(\mathrm{Mn}_{2} \mathrm{O}_{7}\right)$ so that the color change of the solution from dark brown to brownish-black accompanied by bubble bubbles (Figure 2.d). This indicates a fairly high degree of oxidation that occurs (Junaidi and Susanti, 2014). Research Wang et al., (2008) reported that peroxide $\left(\mathrm{H}_{2} \mathrm{O}_{2}\right)$ functions in $\mathrm{GO}$ purification but has not been able to remove metal ions so that metal ion removal uses $\mathrm{HCl}$. The precipitate obtained was subsequently carried out a washing process with $\mathrm{HCl}$ which functions as a metal ion removal agent from the oxidizing residue and was washed to neutral $\mathrm{pH}$ with distilled water repeatedly to reduce residual $\mathrm{SO}_{4}^{-2}$. The washing process has been carried out by exfoliating GO to obtain a black paste. The paste was dissolved into distilled water and through an ultrasonication process aimed at forming GO sheets by peeling off the structure of graphite at the breaking of the Van der Waals force in the interlayer (Ilhami and Susanti, 2014). The synthesis process was obtained GO powder as much as 3.997 grams with a yield of $79.94 \%$. The results of this GO powder are black and from the oxidation reaction, the sample will decrease in its final mass. Furthermore, to identify the compounds produced, FTIR and XRD analysis results are needed.

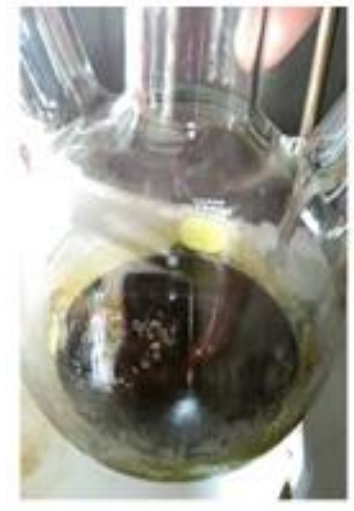

(a)

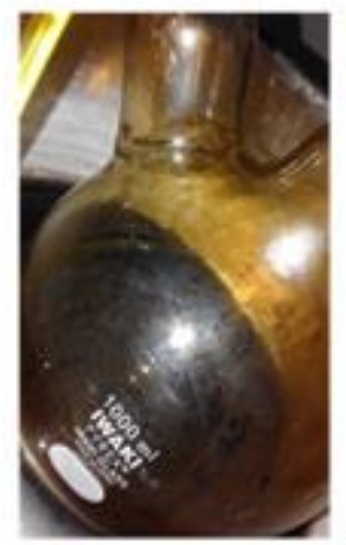

(c)

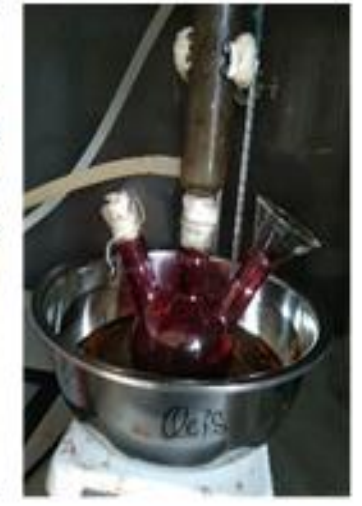

(b)

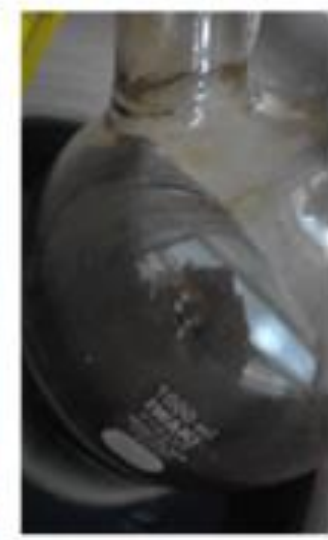

(d)
Figure 2. Color changes that occur during the GO synthesis process.

The XRD results aim to prove that the modification of the Hummers method in GO synthesis with used battery graphite functions actively as a precursor in the synthesis process because in general several studies use natural graphite precursors. Based on the diffractogram Figure 3. GO results appear to 
have sharp peaks overlapping around the diffraction angle (20) $26.4^{\circ}$ which indicates that the peak (002) of graphite has decreased and provides high-intensity data that looks wide at the diffraction angle $23.88^{\circ}$. The diffraction pattern shows the tendency of peak shift (002) from graphite towards the lower diffraction angle. This is because that the synthesis of GO with the graphite oxidation process has been successfully carried out by the oxidizing agent $\mathrm{Mn}_{2} \mathrm{O}_{7}$. However, the diffractogram data shows another peak with high intensity at a diffraction angle of $42.5^{\circ}$. This indicates that there are several of oxidizing agents left in them. The XRD data above is compared with the study of Kumar et al., (2019) so that GO synthesis has been successfully formed which shows similarity to the peak obtained at $2 \theta=23.88^{\circ}$ which is the peak of graphene oxide and at a diffraction angle of $42.5^{\circ}$ which indicates the remaining substance of the oxidizer is potassium graphite.

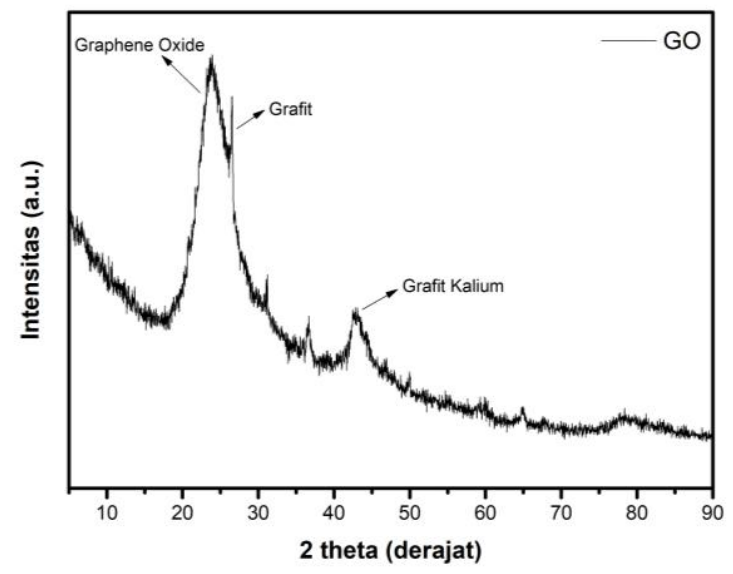

Figure 3. The result of the synthesis diffractogram GO

The next process is the synthesis of GO/PPy composites in a mass ratio (1:10; $3: 10 ; 5: 10$ and 10:10) to form a suspension and a black solution. The polymer initiation process makes the solution turn green with a black suspension, after that the screening process shows that the residue is black and the filtrate is yellow. These results indicate that the composite GO/PPy has been formed and obtained the mass of each composite is 0.492 ; $.958 ; 1,370$; and 2,128 grams. Furthermore, to determine the character of the compounds formed, FTIR characterization is needed. Surface changes due to PPy intercalation can be confirmed using the FTIR spectrum. The results of the FTIR spectrum can be seen in Figure 4. The IR spectrum of the GO/PPy composite compound shows a combination of characteristics similar to pure polypyrrole and GO which includes a broad absorption band located at $3500-2300 \mathrm{~cm}-1$ which is thought to be an amine $(\mathrm{NH})$ stretch of the polypyrrole and hydroxy group $(\mathrm{OH})$ of GO (Salas et al., 2014).

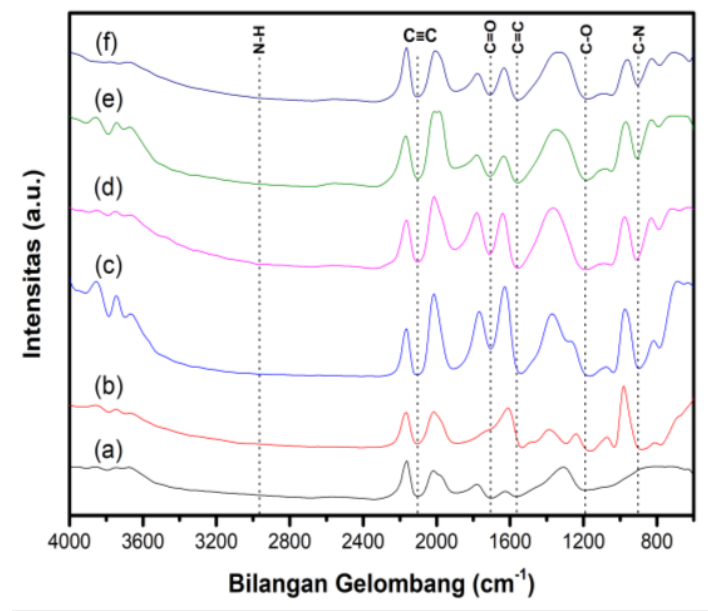

Figure 4. FTIR Spectra (a) GO, (b) PPy, (c) GO/PPy (1:10), (d) GO/PPy (3:10), (e) GO/PPy $(5: 10)$, and (f) GO/PPy $(10: 10)$

The interaction of GO and PPy in terms of the emergence of a new peak in the absorption band of the wavenumber $909 \mathrm{~cm}^{-1}$ is the C-N vibration of the polymerized pyrrole. It is also confirmed that the polypyrrole was successfully inserted into the GO layer that increasing numbers GO mass ratio, then the absorption intensity decreased. This shows that the more PPy interacting with $\mathrm{GO}$, then at the peak of $1710 \mathrm{~cm}^{-1}$ the $\mathrm{C}=\mathrm{O}$ vibration indicated in the $\mathrm{COOH}$ group of $\mathrm{GO}$ decreased the intensity of each mass ratio. The increased peak at wave number $1557 \mathrm{~cm}^{-1}$ is due to the interaction of $\pi-\pi$ hydrogen bonds between the GO layer and the main chain of the aromatic PPy ring. These results are supported by research Fan et al., (2014) and Salas et al., (2014) which shows the similarity in the characteristic absorption peak of composite GO/PPy.

The process of making supercapacitor cells begins with the chemical etching method referring to research by Cheng (2015), this etching process makes the pores larger so that 
the sample can adhere perfectly. Preparations were made with an aluminum plate with an area of $4 \mathrm{~cm}^{2}$ and given a distance of $1 \mathrm{~cm}$. Next, the surface of the plate was dipped with $1 \mathrm{M} \mathrm{NaOH}$ solution and washed with distilled water and dried. These results show the surface of the previous Al plate which previously was not shiny become shiny (clean). The next process is making the electrode composition by mixing PVA composites and binders (90:10) with a total of 0.3 grams. This composition was made for used battery carbon powder, and GO/PPy (1:10; 3:10; 5:10 and 10:10). After each composition is prepared then smeared on a plate and then dried. The drying process has been completed then assembling supercapacitor cells with separators in the form of filter paper and electrolytes in the form of a $1 \mathrm{M} \mathrm{KOH}$ solution. The results of the supercapacitor cell series are shown in Figure 5.

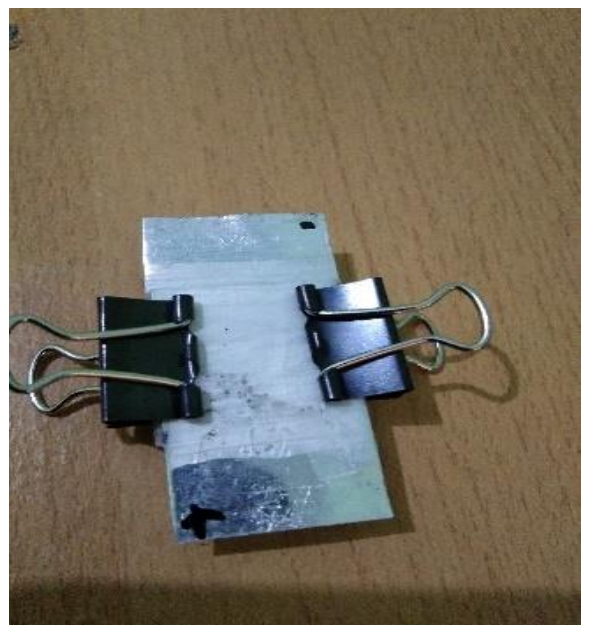

Figure 5. Supercapacitor cell circuit

Supercapacitor cells that have been made are then measured using a SANWA multimeter (CD800A) and KRISBOW LCR meter (KW0600489) to measure voltage, capacitance, and life cycle by measuring charging time and discharging. The results obtained are shown in Table 1.

Based on the measurement results, the supercapacitor cells above use the working principle of electrochemical double-layer capacitors (EDLC) which are based on the inter-surface layer between $\mathrm{GO}$ and $\mathrm{KOH}$ electrolytes as a dielectric. Both GO electrode layers play a role in EDLC filling and emptying due to the mechanism of ion absorption and desorption. Stressing the two layers of electrodes facing each other causes ions to be attracted to the surfaces of both electrodes and the process of charging and vice versa in emptying (Conway, 1999). Whereas conductive polymers namely PPy have the ability between a conductive state with a positive charge to neutral reversibly through the incorporation and release of anionic species from the surrounding solution under oxidation or reduction conditions (Wang, 2000). PPy here becomes an electroactive compound that is positively charged to join the counter ion as a dopant. It is expected that the diffusion of a positive charge of $\mathrm{PPy}^{+}$which is always offset by the mobility of $\mathrm{OH}^{-}$(dopant anion) as a supporting electrolyte on the electrode surface (Murniati et al., 2012). So, the measurement shows that there have been variations in GO and PPy variations in voltage and capacitance. A sharp decrease in stress occurs in the GO/PPy sample (10:10). This is indicated that PPy has not been able to interact $\pi-\pi$ throughout the GO surface area so that GO experiences agglomeration which causes uneven distribution of electron flow and a decrease in voltage.

Therefore, based on the results of measurements have shown that with the best voltage, capacitance and charging time in GO/PPy samples with a ratio (3:10), each of them is $74.1 \mathrm{mV}, 15.14 \mu \mathrm{F}$ and the best filling and emptying time. These results indicate an increase in capacitance compared to the nanocomposite material of the polymer, $\mathrm{CoFe}_{2} \mathrm{O}_{4} / \mathrm{PANi}$ with a capacitance value of $0.0122 \mu \mathrm{F}$ (Nurzam et al., 2019). The addition of polymers, namely PPy succeeded in increasing supercapacitor voltage and capacitance compared to carbon which has a smaller voltage and smaller capacitance than GO/PPy (3:10). This is because GO has a large pore with a high surface area wherein the study of Down et al., (2018) GO has a capacitance value of $76 \mu \mathrm{F}$ in $3 \mathrm{M} \mathrm{KOH}$ so that the nature of GO supports PPy in maintaining the structure of PPy. The PPy structure has an N group thereby accelerating the transfer of electrons in the GO surface area. Therefore in this study, the capacitance value is influenced by the magnitude of the surface area of the composite. 
Table 1. The measurement results in supercapacitor cells

\begin{tabular}{lcccc}
\hline \multicolumn{1}{c}{ Sample } & $\begin{array}{c}\text { Voltage } \\
(\mathbf{m V})\end{array}$ & $\begin{array}{c}\text { Capacitance } \\
(\boldsymbol{\mu} \mathbf{F})\end{array}$ & $\begin{array}{c}\text { Charging } \\
(\mathbf{s})\end{array}$ & $\begin{array}{c}\text { Discharging } \\
(\mathbf{s})\end{array}$ \\
\hline Carbon & 3.5 & 13.30 & 300 & 1682 \\
GO/PPy $(1: 10)$ & 20.2 & 12.55 & 300 & 205 \\
GO/PPy (3:10) & 74.1 & 15.14 & 300 & 579 \\
GO/PPy (5:10) & 80.0 & 11.16 & 300 & 424 \\
GO/PPy (10:10) & 11.0 & 13.10 & 300 & 1190 \\
\hline
\end{tabular}

\section{CONCLUSION}

The graphite preparation stage is carried out by a calcination process $(\mathrm{T}=900$ ${ }^{\circ} \mathrm{C}, \mathrm{t}=2$ hours) producing graphite with an angle of $2 \theta$ is $26.5^{\circ}$ with reflection from the plane $\left(\mathrm{d}_{002}\right)$. FTIR data shows that the GO characteristics of the synthesis results have functional groups identified on the spectrum namely $\mathrm{O}-\mathrm{H}, \mathrm{C}=\mathrm{C}, \mathrm{C} \equiv \mathrm{C}, \mathrm{C}=\mathrm{O}, \mathrm{C}-\mathrm{OH}$, and $\mathrm{C}-\mathrm{O}$ bonds. The XRD analysis results show that the peak at $2 \theta=23.88^{\circ}$ is the peak of graphene oxide and at a diffraction angle of $42.5^{\circ}$ indicates the residual substance of the oxidizer is called potassium graphite. GO/PPy composite FTIR data show a successful combination of characteristics similar to pure polypyrrole and GO which includes a broad absorption band located at $3500-2300 \mathrm{~cm}^{-1}$ which is estimated to be stretching the amine from polypyrrole and $\mathrm{OH}$ groups in the $\mathrm{GO}$ layer and the appearance of new peaks at the absorption band with the wave number 909 $\mathrm{cm}^{-1}$ is the $\mathrm{CN}$ vibration of the polymerized pyrrole. Meanwhile, based on the LCR meter measurement results that the supercapacitor cells with the best voltage, capacitance and charging time in GO/PPy samples with a ratio (3:10) were $74.1 \mathrm{mV}, 15.14 \mu \mathrm{F}$ and charging and emptying time respectively best. In conclusion that the GO/PPy composite has good performance as an electrode in the supercapacitor.

\section{REFERENCES}

Cheng S. 2015. Effect of Aluminum Foil Etching Process on Graphene Super Capacitor. Chemical Engineering Transactions. 46 : 655-660.

Conway BE. 1999. Electrochemical Supercapacitor-Scientific Fundamentals and Technological Applications. New York: Kluwer Academic/Plenum Publishers.
Down MP, Neale SJR, Smith GC, Banks CE. 2018. Fabrication of Graphene oxide supercapacitor devices. ACS Appl. Energy Mater. 1(2): 707-714.

Dreyer DR, Park S, Bielawski CW, Ruoff RS. 2010. The chemistry of graphene oxide. Chem. Soc. Rev. 39(1): 228-240.

Fan LQ, Liu GJ, Wu JH, Liu L, Lin JM, Wei YL. 2014. Asymmetric supercapacitor based on graphene oxide/polypyrrole composite and activated carbon electrodes. Electrochimica Acta. 137: 26-33.

Fialkov AS. 1979. Uglegrafitovye Materialy (Carbon-Graphite Materials). Moscow: Energiya.

Hanifah MFR, Jaafar J, Aziz M, Ismail AF, Rahman MA, Othman MHD. 2015. Synthesis of graphene oxide nanosheets via modified Hummers' method and its physicochemical properties. Jurnal Teknologi. 74(1): 189-192.

Hummers WS, Offeman RE. 1958. Preparation of graphitic oxide. American Chemical Society. 80(6): 1339.

Ilhami M, Susanti D. 2014. Pengaruh massa Zn dan temperatur hydrotermal terhadap struktur dan sifat elektrik material graphene. Jurnal Teknik Pomits. 3(2) : 185-190.

Junaidi M, Susanti D. 2014. Pengaruh variasi waktu ultrasonikasi dan waktu tahan hydrothermal terhadap struktur dan konduktivitas listrik material graphene. Jurnal Teknik Pomits. 3(1): 13-18.

Kumar P, Divya N, Ratan JK. 2019. Synthesis and characterization of chemically derived graphene oxide from graphite. In: Agnihotri A, Reddy K, Bansal A. (eds) Sustainable Engineering. Lecture Notes in Civil Engineering, 30: 85-94. 
Li J, and Xie H. 2012. Synthesis of graphene oxide/polypyrrole nanowire composite for supercapacitors. Material Letters. 78: 106109.

Liu C, Li F, Ma LP, Cheng HM. 2010. Advanced materials for energy storage. Adv. Mater. 22: E28-E62.

Liu Y, Wang H, Zhou J, Bian L, Zhu E, Hai J. 2013. Graphene/polypyrrole intercalating nanocomposites as supercapacitors electrode. Electrochimica Acta. 112: 44-52.

Murniati A, Buchari, Gandasasmita S, Nurachman. 2012. Sintesis dan karakterisasi polipirol pada elektroda kerja kasa baja dengan metode voltametri siklik. Indonesian Journal of Materials Science. 13(3): 210-215.

Nurzam FRP, Ramli and Ratnawulan. 2019. Pengaruh komposisi $\mathrm{CoFe}_{2} \mathrm{O}_{4}$ terhadap sifat listrik nanokomposit $\mathrm{CoFe}_{2} \mathrm{O}_{4} / \mathrm{PANi}$ yang disintesis dengan metoda sol-gel. Pillar of Physics. 12(1): 38-45.

Popova AN. 2017. Crystallographic analysis of graphite by X-Ray diffraction. Coke and Chemistry. 60(9): 32-36.

Salas IMDF, Sudhakar YN, and Selvakumar M. 2014. High performance of symmetrical supercapacitor based on multilayer films of graphene oxide/polypyrrole electrodes. Applied Surface Science. 296: 195-203.

Saraswati TE, Bahrudin A, and Anwar M. 2016. Pengaruh suhu pemanasan dan agen pengikat dalam pembuatan konduktor listrik berbasis arang. ALCHEMY Jurnal Penelitian Kimia. 12(2): 167-178.
Socrates G. 2001. Infrared and Raman Characteristic Group Frequencies. New York: Wiley and Sons.

Stoller MD, Park S, Zhu Y, An J, Rouff RS. 2008. Graphene-Based Ultracapacitors. Nano Letters. 8(10): 3498-3502.

Syakir N, Nurlina R, Anam S, Aprilia A, Hidayat S, Fitrilawati. 2015. Kajian pembuatan oksida grafit untuk produksi oksida grafena dalam jumlah besar. Jurnal Fisika Indonesia. 55(19): 26-29.

Wachid FM, Darminto. 2012. Analisis fasa karbon pada proses pemanasan temputung kelapa. Jurnal Teknik Pomits. 1(1): 1-4.

Wang G, Yang J, Park J, Gou X, Wang B, Liu H, Yao J. 2008. Facile synthesis and characterization of graphene nanosheets. The Journal of Physical Chemistry C. 112: 81928195.

Wang H, Zhu E, Yang J, Zhou P, Sun D, Tang WH. 2012. Bacterial cellulose nanofibers supported polyaniline nanocomposite with flake-shape morphology as supercapacitor electrodes. J. Phy. Chem. 116: 13013-13019.

Wang J. 2000. Analytical Electrochemistry. New York: Wiley and Sons.

Winter W, Brodd RJ. 2004. What are batteries, fuel cells, and supercapacitors. Chem. Rev. 104: 4245-4270.

Zhai Y, Dou Y, Zhao D, Fulvio PF, Mayes RT, Dai S. 2011. Carbon materials for chemical capasitive energy storage. Adv. Mat. 23(42): 4828-4850. 